\title{
Neustonic patch of Moreiradromia antillensis (Stimpson, 1859) (Crustacea: Brachyura: Dromiidae) megalopae over the shelf-break: evidence of synchronism in pre-settlement larval pool
}

\author{
EdUARdo Vianna de AlmeidA ${ }^{1 *}$, LOHENGRIN DiAs DE ALMEIDA FERNANDES ${ }^{2}$ \& \\ SÉRGIO LUIZ COSTA BONECKER ${ }^{1}$ \\ ${ }^{1}$ Departamento de Zoologia, Instituto de Biologia da Universidade Federal do Rio de Janeiro (UFRJ). Av. \\ Carlos Chagas Filho, n. 373, Centro de Ciências da Saúde (CCS) - Cidade Universitária, Rio de Janeiro - \\ RJ, Brasil. CEP: 21941-902 \\ ${ }^{2}$ Laboratório de Plâncton e Microbiologia Marinha, Instituto de Estudos do Mar Almirante Paulo Moreira, \\ Departamento de Biotecnologia Marinha, Divisão de Biotecnologia Aplicada. R. Kioto, 253, Praia dos \\ Anjos, Arraial do Cabo, RJ - Brasil. CEP: 28930-000.
}

*Corresponding author: vianna.almeida@gmail.com

\begin{abstract}
This study reports for the first time patches of Moreiradromia antillensis megalopa in superficial waters over the shelf-break and addresses their relevance as evidence of synchronism in the planktonic larval pool. Patches were registered during a plankton survey conducted between $13^{\circ}$ and $22^{\circ} \mathrm{S}$, over the shelf break in the central coast of Brazil.
\end{abstract}

Key words: Sponge crab, Decapod larvae, Patchiness, Brazilian Coast.

Resumo: Manchas neustônicas de megalopas de Moreiradromia antillensis (Crustacea: Brachyura: Dromiidae) sobre a quebra da plataforma: evidência de sincronismo no estoque larval pré-assentamento. Este estudo relata pela primeira vez, manchas de megalopas de Moreiradromia antillensis em águas superficiais da plataforma e discute sua relevância como evidência de sincronismo na formação de pool larval. Manchas foram registradas em estudo do plâncton entre $13^{\circ}$ e $22^{\circ} \mathrm{S}$, sobre a quebra de plataforma na Costa Central do Brasil.

Palavras-chave: Caranguejo-esponja, larvas de Decapoda, Agrupamento, Costa brasileira.

The Family Dromiidae belongs to the Infraorder Brachyura and includes crabs with cryptic behavior that inhabit rocky or reef bottoms (Melo et al. 1998). The dromiid crab Moreiradromia antillensis (Stimpson, 1859) is widely distributed in the Atlantic Ocean (eastern shores of the Americas), being registered from the intertidal region to deeper waters (500m) (OBIS 2019). Some dromiid crabs like $M$. antillensis usually carry small fragments of sea squirts and sponges attached to the dorsal region of the carapace, which has earned them the popular name of 'sponge crabs' (Melo 1996). The larval development of $M$. antillensis was first described back in the $60 \mathrm{~s}$, under laboratory conditions. The metamorphosis seems to be affected by the water temperature, ranging from 23 to 37 days after hatching (Rice \& Provenzano 1966). The larval phase comprises six zoeal stages and one megalopa, the settler stage. The settlement is an obligate event for any benthic marine invertebrate that has a planktonic larval phase. It means that larvae must survive into the plankton until the transition to the benthic realm when larvae descend in the water column to settle on the substrate (Jenkins et al. 2009). Therefore, the success rate in the settlement may affect the number of recruits and consequently the replenishment of the adult population (Menge 2000). By combining the avoidance and the swamping hypothesis (Ims 1990, Morgan \& Christy 1997), most authors agree that synchronisms in nocturnal spawning, larval molting, and vertical migration represent a key factor in the settlement 
success (e.g. Menge 1991, Fraschetti et al. 2002, Yoshinaga et al. 2010). From that time, little information about the $M$. antillensis larvae in the natural environment was added to our knowledge, including larval pool, synchronism, and settlement behavior. Thus, the present work registers for the first time five patches of $M$. antillensis megalopa over the shelf-break in the Central Coast of Brazil and discusses their importance as a pre-settlement phenomenon.

The sampling of the present study was done during the "Central VI" campaign of the 'REVIZEE' Project (Living Resources of the Exclusive Economic Zone) on the shelf and shelf-break between $13^{\circ}-22^{\circ} \mathrm{S}$ in the South Atlantic Ocean (Brazil). During 16 days in the austral winter of 2002, a set of 17 stations were surveyed between $13^{\circ}$ - $22^{\circ} \mathrm{S}$ and $037^{\circ}-041^{\circ} \mathrm{W}$ (Table I) that lead to 34 zooplankton samples obtained with a modified David-Hempel Catamaran net $(30 \mathrm{~cm}$ x $30 \mathrm{~cm}$ x 2 $\mathrm{m})$ (Calazans et al. 2011). This sample apparatus includes a floating catamaran with two overlapping nets ( 17 stations $\mathrm{x} 2$ nets $=34$ samples) with a 500 $\mu \mathrm{m}$ mesh opening, which collected simultaneously at depths $0=15 \mathrm{~cm}$ (upper net, with nearly $10 \mathrm{~cm}$ outer of water) and $15=30 \mathrm{~cm}$ (lower net). Each trawl had an average speed of 2.0 knots and lasted around 10 minutes. A mechanic flowmeter (G.O. 2030R) was attached to the lower net, to prevent any contact with the air the occurs in the upper net and thus estimating the area covered in each trawl $\left(\mathrm{m}^{2}\right)$. In the laboratory, the megalopae were sorted, identified, and counted according to Rice and Provenzano (1966) using a Zeiss stereomicroscope (80x), and then collectively weighted on an Ainsworth precision scale $(0.0001 \mathrm{~g})$ to estimate biomass $\left(\mathrm{g} .100 \mathrm{~m}^{-2}\right)$. The abundance was expressed by the number of megalopae per $100 \mathrm{~m}^{-2}$ (ind. $100 \mathrm{~m}^{-}$ $\left.{ }^{2}\right)$. To estimate the individual average weight (average per capita weight; ApW), the biomass was divided by the abundance $\left(\mu\right.$ g.ind $\left.{ }^{-1}\right)$.

Megalopae of $M$. antillensis were registered in five (29\%) of 17 sampling sites done over the shelf break between $13^{\circ} \mathrm{S}$ and $22^{\circ} \mathrm{S}$. Most larvae occur in patches with an average abundance equal to 36.9 ind.100 $\mathrm{m}^{-2}$, in the central coast (Fig. 1). The megalopa abundance and wet weight ranged respectively from 4.0 to 339 ind $100 \mathrm{~m}^{-2}$ and from 0.89 to 64.75 g. $100 \mathrm{~m}^{-2}$ (Table I). Although not significant $(\mathrm{p}>0.05)$, slightly higher abundances were found during the night (Fig. 2) in areas with a local depth ranging from 400 to $1000 \mathrm{~m}$. Similarly, the patches of megalopae were evenly distributed

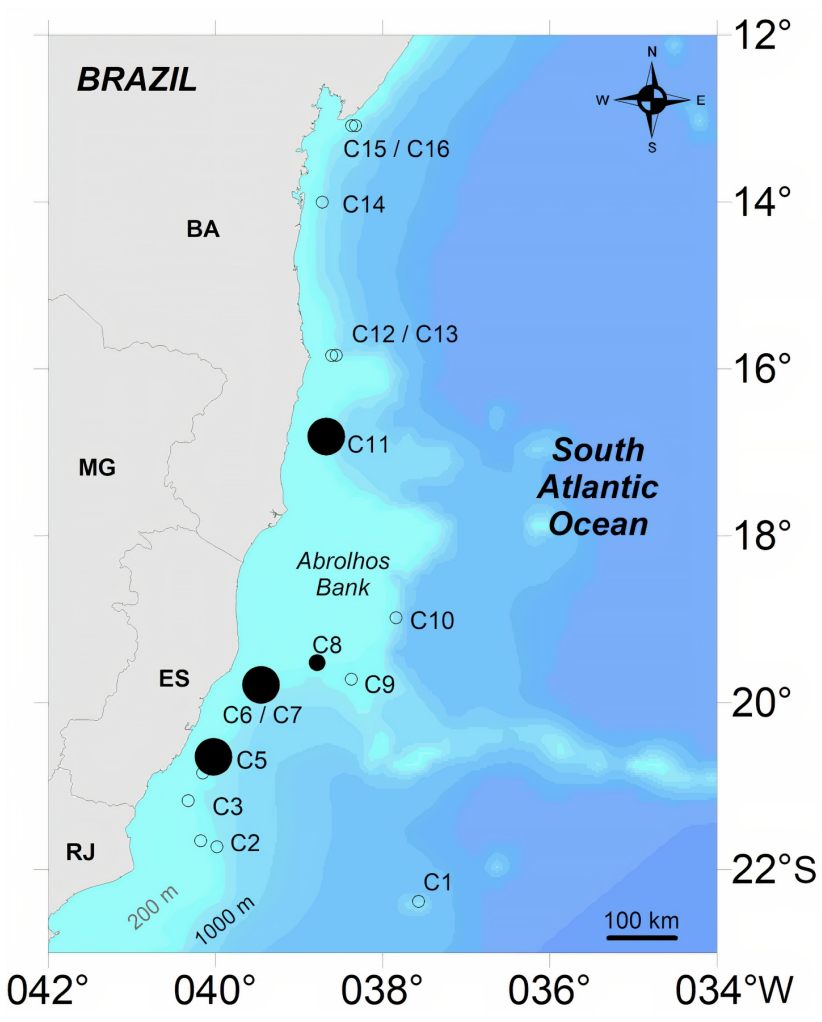

Figure 1. Spatial distribution of Moreiradromia antillensis megalopae over the shelf break in the central coast of Brazil during the 2002 winter. Stations (circles) marked in black represent occurrences of $M$. antillensis megalopae with either low abundance (small black circle; $<18$ megalopae. $100 \mathrm{~m}^{-2}$ ) or high abundance (large black circles; >18 megalopae. $100 \mathrm{~m}^{-2}$ ). Stations C6 and C7 overlap in the map due to their proximity.

between $0-10 \mathrm{~cm}$ and $10-30 \mathrm{~cm}$ in most stations but concentrated at the superficial layer $(0-10 \mathrm{~cm}$ depth) since the majority of larvae were caught in the upper net (Fig. 2). The estimated average weight of a single megalopa ranged from 28 to $97 \mu \mathrm{g}$. Four of the five samples with megalopae were done during the phase of the new moon.

Like other meroplanktonic organisms, crustacean decapods develop through a sequence of morphological and physiological changes from hatching to the recruitment into the juvenile phase (Anger 2001). Nevertheless, little is known about the larval dynamics of oceanic and cryptic species, like the sponge-crab $M$. antillensis to provide useful information about the management and conservancy of coralline species. New data focusing on the larval behavior and spatial distribution, like the occurrence of high dense patches of megalopae, are evidence of synchronism as a strategy in the pre-settlement larval pool, usually found in crustaceans in estuarine 
Table I. Hour (initial, UTC-3), date, coordinates, local depth, sampled area $\left(\mathrm{m}^{2}\right)$, abundance (ind.100 $\left.\mathrm{m}^{-2}\right)$, and wet weight $\left(\mathrm{g} .100 \mathrm{~m}^{-2}\right)$ in the neuston trawls done in the central Brazilian coast during the 2002 winter.

\begin{tabular}{|c|c|c|c|c|c|c|c|c|}
\hline \multirow[b]{2}{*}{$\begin{array}{c}\text { Sample } \\
\text { point }\end{array}$} & \multirow[b]{2}{*}{$\begin{array}{l}\text { Local } \\
\text { time }\end{array}$} & \multirow[b]{2}{*}{ Date } & \multicolumn{2}{|c|}{ Haul coordinates } & \multirow[b]{2}{*}{$\begin{array}{l}\text { Local } \\
\text { depth } \\
(\mathrm{m})\end{array}$} & \multirow[b]{2}{*}{$\begin{array}{c}\text { Sampled } \\
\text { area } \\
\left(\mathrm{m}^{2}\right)\end{array}$} & \multirow[b]{2}{*}{$\begin{array}{l}\text { Abundance } \\
\text { upper/lower } \\
\text { (ind.100m-2) }\end{array}$} & \multirow[b]{2}{*}{$\begin{array}{l}\text { WetWeight } \\
\text { upper/lower } \\
\left(\text { g. } 100 \mathrm{~m}^{-2}\right)\end{array}$} \\
\hline & & & $\begin{array}{l}\text { Latitude (S) } \\
\text { starting point }\end{array}$ & $\begin{array}{c}\text { Longitude (W) } \\
\text { starting point }\end{array}$ & & & & \\
\hline C5 & $14: 56$ & 14.vi.2002 & 20³9'03" & $040^{\circ} 01^{\prime} 26^{\prime \prime}$ & 54 & 352 & $6.70 / 13.70$ & $0.12 / 0.53$ \\
\hline C6 & $06: 55$ & 15.vi.2002 & $19^{\circ} 45^{\prime} 51^{\prime \prime}$ & 039³1'11" & 68 & 311 & $9.25 / 5.28$ & $0.35 / 0.06$ \\
\hline $\mathrm{C} 7$ & $19: 21$ & 15.vi.2002 & 1947'12" & 039²7'10" & 1000 & 423 & $14.56 / 3.64$ & $0.78 / 0.03$ \\
\hline C8 & $13: 10$ & 18.vi.2002 & 19³1'20" & 0384'ㄷ'" & n.r. & 242 & $1.27 / 2.55$ & $0.24 / 0.13$ \\
\hline C11 & $23: 25$ & 20.vi.2002 & $16^{\circ} 48^{\prime} 46^{\prime \prime}$ & 0384'ㄹ'" & 413 & 310 & 338.9/0.00 & 23.77/0.00 \\
\hline
\end{tabular}

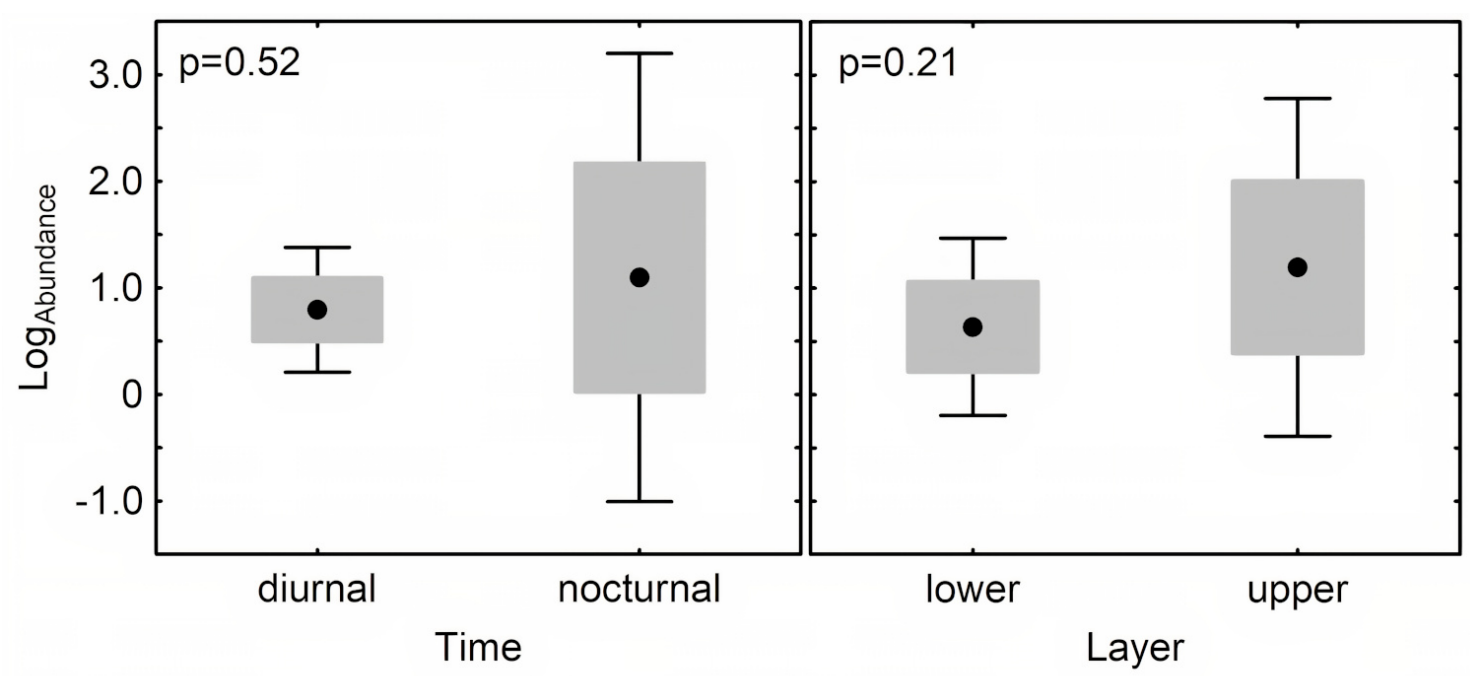

Figure 2- BoxPlot $(\bullet=$ mean, gray area=mean \pm SD, spread bars=mean $\pm 1,96 * S D)$ and significance of the Student $t-T e s t$ (p superimposed in the graph) calculated on the Log-abundance (ind.100 $\mathrm{m}^{-2}$ ) of $M$. antillensis megalopa collected in five sites in the Central Brazilian Coast under daily cycle (diurnal versus nocturnal timing) and distinct layers (upper net $=0-10 \mathrm{~cm}$; lower net $=10-30 \mathrm{~cm}$ depth).

regions (Fernandes et al. 2002). Megalopae are strong swimmers and can perform vertical migrations with relative ease (Shanks 1995). The megalopa of $M$. antillensis, however, are heavier, more opaque and rounded than other traditional neustonic organisms, like the transparent, thin, light and planned phyllosoma, thus being apparently incompatible with a neustonic lifestyle. This leads us to focus on the high concentration observed in a very superficial thin layer $(<10 \mathrm{~cm})$ in the South Atlantic Ocean. In general, the association of organisms with superficial layers is regarded as a strategy to increase wind-driven dispersion (Morgan 2020), even though it imposes a high risk of injury due to UV radiation (Häder et al. 2015). In this particular scenario, the concentration of megalopae as patches in the very thin superficial layer during the night fits into both dispersion and avoidance hypotheses (Christy \& Morgan 1998, Paula et al. 2004).

Like other particles that accumulate on the surface under the influence of convergent currents (Olson 1991), high-density patches of megalopae could arise as a concentration of suspended particles due to a combination of ontogenetic synchronism and physical processes. The high abundance of megalopae in regions susceptible to the occurrence of oceanic fronts as the shelf-break supports this hypothesis. The water column in the tropical shelfbreak of the Brazilian central basin is strongly stratified, where the warmer and saltier superficial oceanic water flows southward and interacts with a cooler and less salty deep water. Under this situation, the shelf-break is marked by strong pycnocline and circular flows as meanders and 
vortices of the Brazilian Current (RossiWongtschowski et al. 2006, Soutelino et al. 2011), where suspended elements tend to aggregate (Olson 1991). Besides oceanic fronts and vortices, other combinations between synchronism and physical forces as internal waves also resulted in similar aggregation of plankton and an occasional patch of megalopae (Shanks 1995). Rather than be a passive particle, the concentration of megalopa in the superficial layer could be partially explained by a species-specific strategy. Could the megalopae patch be related to a foraging strategy? An ichthyoplankton survey simultaneously conducted revealed the absence of fish eggs and a comparatively low abundance of fish larvae coincident to the densest patch of $M$. antillensis megalopae in C11 station (Bonecker 2007). Even though that uncertainty remains about the causality regarding that coincidence, vertical migration related to feeding could not be discarded, considering that the megalopae of Brachyura can act as both pelagic and benthic predators (Anger 2001).

Distant around 30 nautic miles from the C11 station (where the biggest patch was found), the closest known adult population of $M$. antillensis inhabits a coral reef area (40 m local depth) in the north of Abrolhos (16 ${ }^{\circ} 7^{\prime} 1.00$ "S, 038 $\left.{ }^{\circ} 10^{\prime} 12.00^{\prime \prime} \mathrm{W}\right)$ (Serejo et al. 2006). Besides adults of the sponge crab, Lavrado and Ignacio (2006) also found a large assemblage of organisms usually co-occurring with the adults of $M$. antillensis, like algae, sponges, and the coral Siderastrea stellata Verrill, 1868. This indicates that the megalopae patch of the C11 may have been transported southward following both the prevailing NE wind and the Brazilian current in the region. In the laboratory, the megalopae of $M$. antillensis can last for two weeks (14.5 days at $25^{\circ} \mathrm{C}$ ) (Rice \& Provenzano 1966) and perhaps even more if settlement conditions are not fulfilled (Gebauer et al. 2020). Additionally, patch integrity can persist for days (Morgan 2020) leading us to argue if the megalopae are adopting a strategy to avoid predation and increase synchronism. In decapods, the gregarious behavior of pre-settlers and the synchronic settlement has been recorded for distinct taxonomic groups (Tabeta \& Kanamaru 1970, Kawamura 1976, Rice \& Kristensen 1982, Hartnol et al. 2014). Synchronism of megalopae in high-density patches can result in a settler-saturated condition when most larvae simultaneously search for a proper place for settlement. A synchronized settlement leads to increasing in megalopae survival, which in turn minimizes the uncoupling between recruitment and replenishment of adult populations (Menge 1991). Therefore, our findings not only report for the first time a massive concentration of $M$. antillensis megalopae over the shelf-break, but reveal new data regarding synchronism in the presettlement larval pool.

\section{Acknowledgements}

We thank Dr. Jean Louis Valentin, coordinator of the REVIZEE Program's Central Score, and the staff of the RV Thalassa (IFREMER) who worked on the Central IV campaign.

\section{References}

Anger, K. 2001. The Biology of Decapod Crustacean Larvae. Crustacean Issues 14. A. A. Balkema Publishers, Lisse, 419 p.

Bonecker, A. C. T. 2007. Ictionêuston. Pp. 161168. In: Valentin, J. L. (Ed.). Características hidrobiológicas da região central da Zona Econômica Exclusiva (Salvador, BA, ao Cabo de São Tomé, RJ). Brasília: Ideal Gráfica e Editora, 168 p.

Calazans, D., Muelbert, J. H. \& Muxagata, E. 2011. Organismos Planctônicos. Pp. 200-275. In: Calazans, D. (Ed.). Estudos Oceanográficos: do instrumental ao prático. Textos, Pelotas, $464 \mathrm{p}$.

Christy, J. H. \& Morgan, S. G. 1998. Estuarine immigration by crab postlarvae: mechanisms, reliability and adaptive significance. Marine Ecology Progress Series, 174: 51-65.

Fernandes, L. D. A., Bonecker, S. L.C. \& Valentin, J. L. 2002. Dynamic of decapod crustacean larvae on the entrance of Guanabara bay. Brazilian Archives of Biology and Technology, 45(4): 491-498.

Fraschetti, S., Giangrande, A., Terlizzi, A. \& Boero, F. 2002. Pre- and post-settlement events in benthic community dynamics. Oceanologica Acta, 25: 285-295.

Gebauer, P., Giménez, L., Hinojosa, I. A. \& Paschke, K. 2020. Settlement and metamorphosis in barnacles and decapods. Pp. 223-253. In: Anger, K., Harzsch, S. \& Thiel, M. (Eds.). The Natural History of the Crustacea, Volume VII: Developmental Biology and Larval Ecology. Academic Press, New York, 445 p.

Hartnoll, R. G., Weber, N., Régnier-Mckellar, C. \& Weber, S. B. 2014. Return to the land; The 
stages of terrestrial recruitment in land crabs. Crustaceana, 87: 531-539

Häder, D. P., Williamson, C. E., Wängberg, S. Å., Rautio, M., Rose, K. C., Gao K., Helbling, E. W., Sinhah, R. P. \& Worresti, R. 2015. Effects of UV radiation on aquatic ecosystems and interactions with other environmental factors. : Photochemical and Photobiology Sciences, 14: 108-126.

Ims, R. A. 1990. The ecology and evolution of reproductive synchrony. The American Naturalist, 136: 485-498.

Jenkins, S. R., Marshall, D. \& Fraschetti, S. 2009. Settlement and Recruitment. Pp. 177-190. In: Wahl, M. (Ed.). Marine Hard Bottom Communities. Ecological Studies, Volume 206. Springer-Verlag, Heidelberg, 445 p.

Kawamura, A. 1976. A note on the surface swarm of lobster-krill, Munida gregaria (Crustacea, Decapoda, Galatheidae). Bulletin of the Plankton Society of Japan, 23: 13-18.

Lavrado, H. P. \& Ignácio, B. L. (Eds.). 2006. Biodiversidade bentônica da região central da Zona Econômica Exclusiva brasileira. Série Livros - Museu Nacional, Rio de Janeiro, 389 p.

Melo, G. A. S. 1996. Manual de identificação dos Brachyura (caranguejos e siris) do litoral brasileiro. Editora Plêiade, São Paulo, 604 p.

Melo, G., Torres, M. F. A. \& Campos Jr., O. 1998. Dromiacea and Oxystomata. Pp. 439-454. In: Young, P. S. (Ed.). Catalogue of Crustacea of Brazil. Museu Nacional, Rio de Janeiro, $717 \mathrm{p}$.

Menge, B. A. 1991. Relative importance of recruitment and other causes of variation in rocky intertidal community structure. Journal of Experimental Marine Biology and Ecology, 146 (1): 69-100.

Menge, B. A. 2000. Recruitment vs. Post recruitment processes as determinants of barnacle population abundance. Ecological Monographs, 70 (2): 265-288.

Morgan, S. G. 2020. Dispersal. Pp. 383-407. In: Anger, K., Harzsch, S. \& Thiel, M. (Eds.). The Natural History of the Crustacea, Volume VII: Developmental Biology and Larval Ecology. Academic Press, New York, $445 \mathrm{p}$.

Morgan, S. G. \& Christy, J. H. 1997. Planktivorous fishes as selective agents for reproductive synchrony. Journal of Experimental Marine Biology and Ecology, 209: 89-101.
OBIS. 2019. Moreiradromia antillensis (Stimpson, 1859). Ocean Biodiversity Information System, accessible at https://obis.org/taxon/421894 (Accessed 04/01/2021)

Olson, D. B. 1991. Rings in the ocean. Annual Review of Earth and Planetary Sciences, 19: 283-311.

Paula, J., Bartilotti, C., Dray, T., Macia, A. \& Queiroga, H. 2004. Patterns of temporal occurrence of brachyuran crab larvae at Saco mangrove creek, Inhaca Island (South Mozambique): implications for flux and recruitment. Journal of Plankton Research, 26(10): 1163-1174.

Rice, A. L. \& Provenzano, Jr., A. J. 1966. The larval development of the West Indian sponge crab Dromidia antillensis (Decapoda: Dromiidae). Journal of Zoology, 149: 297319.

Rice, A. L. \& Kristensen, I. 1982. Surface swarms of swimming crab megalopae at Curacao (Decapoda, Brachyura). Crustaceana, 42: 233-240.

Rossi-Wongtschowski, C. L. D. B., Valentin, J. L., Jablonski, S., Amaral, A. C, Z., Hazin, F. H. V., \& El-Robrini, M. 2006. O Ambiente Marinho. Pp. 21-75. In: Ministério do Meio Ambiente (Org.). Relatório Executivo Programa REVIZEE, Avaliação do potencial sustentável de recursos vivos da Zona Econômica Exclusiva do Brasil. MMA, Brasília, 303 p.

Serejo, C. S., Young, P. S., Cardoso, I. A., Tavares, C. R. \& Abreu Junior, C. R. 2006. Filo Arthropoda - Subfilo Crustacea. Pp. 13-389. In: Lavrado, H. P. \& Ignácio, B. L. (Eds.). 2006. Biodiversidade bentônica da região central da Zona Econômica Exclusiva brasileira. Série Livros - Museu Nacional, Rio de Janeiro, 389 p.

Shanks, A. L. 1995. Mechanisms of cross-shelf dispersal of larval invertebrates and fish. Pp. 324-367. In: McEdward, L. R. (Ed.). Ecology of marine invertebrate larvae. CRC, Boca Raton, 480 p.

Soutelino, R. G., Silveira, I. C. A., Gangopadhyay, A. \& Miranda, J. A. 2011. Is the Brazil Current eddy-dominated to the north of $20^{\circ}$ S? Geophysical Research Letters, 38(3): L03607

Tabeta, O. \& Kanamaru, S. 1970. On the post larvae of Munida gregaria (Crustacea, 
Galatheidae) in Penas Bay, Chile, with reference to mass occurrence in 1969. Science Bulletin of the Faculty of Agriculture, 24: 227-23.

Yoshinaga, M. Y., Sumida, P. Y. G., Silveira, I. C. A., Ciotti, A. M., Gaeta, S. A., Pacheco, L. F.
C. M. \& Koettker, A. G. 2010. Vertical distribution of benthic invertebrate larvae during an upwelling event along a transect off the tropical Brazilian continental margin. Journal of Marine Systems, 79: 124-133.

Received: April 2021 Accepted: November 2021 Published: November 2021 